\title{
Synapses on Sympathetic Neurons and Parasympathetic Neurons Differ in Their Vulnerability to Diabetes
}

\author{
Alona Rudchenko, Eli Akude, and Ellis Cooper \\ Department of Physiology, McGill University, Montreal, Quebec, Canada, H3G 1Y6
}

\begin{abstract}
Synapses in autonomic ganglia represent the final output of various CNS structures that regulate the function of the periphery. Normally, these excitatory cholinergic-nicotinic synapses produce large suprathreshold EPSPs on sympathetic and parasympathetic neurons to convey signals from the CNS. However, in certain disease states, synaptic transmission in autonomic ganglia is depressed and the periphery becomes deregulated. For example, previous work demonstrated that hyperglycemia depresses EPSPs on sympathetic neurons and disrupts sympathetic reflexes by causing an ROS-dependent inactivation of the postsynaptic nAChRs. What is not clear, however, is whether some autonomic neurons are more vulnerable to hyperglycemia than others. One possibility is that sympathetic neurons may be more prone than cholinergic parasympathetic neurons to hyperglycemia-induced elevations in cytosolic ROS because sympathetic neurons contain several pro-oxidant molecules involved in noradrenaline metabolism. To test this hypothesis, we recorded synaptic transmission from different mouse sympathetic and parasympathetic ganglia, as well as from the adrenal medulla. In addition, we used cellular imaging to measure hyperglycemia-induced changes in cytosolic ROS and whole-cell recordings to measure the use-dependent rundown of ACh-evoked currents. Our results demonstrate that hyperglycemia depresses synaptic transmission on sympathetic neurons and adrenal chromaffin cells and elevates cytosolic ROS. Conversely, hyperglycemia has little effect on synaptic transmission at synapses on parasympathetic neurons. We conclude that sympathetic neurons and adrenal chromaffin cells are more vulnerable to diabetes than parasympathetic neurons, a finding that may have implications for both long-term diabetic autonomic neuropathies and insulin-induced hypoglycemia, a serious complication of diabetes.
\end{abstract}

Key words: adrenal medulla; autonomic nervous system; hyperglycemia; nicotinic receptors; reactive oxygen species; synaptic transmission

\section{Introduction}

Most people with diabetes develop problems with their autonomic nervous system that severely affect their quality of life and shorten their life expectancy. Symptoms range in severity and include cardiac arrhythmias, orthostatic hypotension, gastrointestinal abnormalities, and poor control of the circulation (Vinik et al., 2003; Freeman, 2005; Vinik and Ziegler, 2007; Kuehl and Stevens, 2012). There is much about this complication that is poorly understood. One puzzling aspect is that diabetes does not seem to affect all autonomic nerves in the same way. For example, research on patients with diabetes shows that many sympathetic nerve endings in the prevertebral superior mesenteric and celiac ganglia are significantly enlarged and appear dystrophic (Schmidt, 1996); however, there are no structural abnormalities in the paraver-

Received Jan. 4, 2014; revised April 28, 2014; accepted May 20, 2014.

Author contributions: E.C. designed research; A.R. and E.A. performed research; A.R., E.A., and E.C. analyzed data; E.C. wrote the paper.

This work was supported by funds from Juvenile Diabetes Research Foundation (JDRF) and Canadian Institutes of Health Research (E.C..). A.R. was supported in part by a Natural Sciences and Engineering Research Council of Canada graduate studentship. E.A. was supported by a postdoctoral award from JDRF. We thank Prof. L. Cooper for her careful reading of our manuscript.

The authors have no competing financial interests.

Correspondence should be addressed to Dr. Ellis Cooper, Department of Physiology, McGill University, McIntyre Medical Sciences Building, Room 1127, 3655 Promenade Sir William Osler, Montreal, Quebec, Canada, H3G 1Y6. E-mail: ellis.cooper@mcgill.ca.

DOI:10.1523/JNEUROSCI.0033-14.2014

Copyright $\odot 2014$ the authors $\quad 0270-6474 / 14 / 348865-10 \$ 15.00 / 0$ tebral sympathetic ganglia, ganglia involved in regulating the cardiovascular system (Schmidt et al., 2008, 2009). Because there are no morphological changes in paravertebral ganglia, these findings suggest that diabetic cardiovascular dysautonomia result from functional rather than structural defects. Consistent with this idea, we discovered recently that diabetic mice have functional defects in the paravertebral superior cervical ganglia (SCGs). Briefly, we showed that hyperglycemia elevates reactive oxygen species (ROS) in SCG neurons; ROS then act on highly conserved cysteine residues located in $\alpha 3, \beta 2$, and $\beta 4$ nicotinic acetylcholine receptor (nAChR) subunits near the intracellular mouth of the receptor pore to depress ganglionic synaptic transmission and reduce the function of sympathetic reflexes (Campanucci et al., 2010; Krishnaswamy and Cooper, 2012).

The question is: how widespread is this mechanism in the autonomic nervous system? Specifically, does hyperglycemia inactivate postsynaptic nAChRs and depress synaptic transmission in all autonomic ganglia and the adrenal medulla, a gland that is directly involved in the defense against insulin-induced hyperglycemia. For this to be the case, two criteria must be satisfied: (1) the postsynaptic nAChRs must contain the conserved cysteine residues; and (2) hyperglycemia should lead to an elevation in cytosolic ROS. Concerning postsynaptic nAChRs, for neurons in many autonomic ganglia, the nAChR subtypes have not been fully resolved. Although there is good evidence that $\alpha 3$ containing $\mathrm{nAChRs}$ are present on many autonomic neurons, 
there is evidence that synaptic transmission in parasympathetic neurons in chicks is mediated by both $\alpha 3$-containing nAChRs and $\alpha 7$-containing nAChRs (Zhang et al., 1996; Ullian et al., 1997), a subtype that lacks the conserved cysteine (Krishnaswamy and Cooper, 2012). As for the adrenal medulla, there is evidence that these cells express $\alpha 7$ or $\alpha 9$ nAChR subunits, as well as $\alpha 3$ (Criado et al. 1997; Colomer et al. 2010). Nor is there much information about hyperglycemia-induced elevations in cytosolic ROS in autonomic neurons. Do all autonomic neurons respond similarly?

To address these issues, we investigated synaptic transmission in three branches of the autonomic nervous system: (1) a prevertebral sympathetic ganglion, the superior mesenteric; (2) a parasympathetic ganglion, the submandibular; and (3) the adrenal medulla. Synaptic transmission is markedly depressed in the superior mesenteric ganglia (SMGs) and in the adrenal medulla but, unexpectedly, not in parasympathetic ganglia. Using combined ROS imaging and electrophysiology, we show that this differential effect on synaptic transmission occurs because sympathetic neurons are more vulnerable to hyperglycemia-induced oxidative stress than parasympathetic neurons.

\section{Materials and Methods}

Animals

We used 1- to 5-month-old wild-type (WT) and homozygote $\alpha 3 \mathrm{nAChR}$ subunit gene-null mice ( $\alpha 3 \mathrm{KO}$; gift from Dr. A. Beaudet, Baylor School of Medicine, Houston, TX) on outcrossed C57BL/6/J $\times$ CD1 background. To obtain these animals, we mated male and female heterozygous $(\alpha 3+/-)$ mice and genotyped the offspring by PCR (WT forward primer, 5'-GTGGATCCCTCCGGCCATCTTTAAGAG; WT reverse primer, 5' -GACTGTGATGACAATGGACAAGGTGAC; and mutant reverse primer, 5'-TGGCGCGAAGGGACCACCAAAGAACGG). Male and female homozygote $\alpha 3 \mathrm{KO}$ mice and age-matched WT littermates were used for experiments.

Models of type 1 diabetes. To mimic type 1 diabetes, we used two models: (1) Akita (C57BL/6J-Ins2 ${ }^{\text {Akita }}$ ) mice (The Jackson Laboratory); and (2) WT C57BL/6/J $\times$ CD1 mice injected with streptozotocin (STZ), a toxin that kills insulin-producing pancreatic $\beta$ cells.

Akita (C57BL/6J-Ins $\left.2^{\text {Akita }}\right)$ mice. Heterozygous male Akita mice developed high blood glucose ( $>20 \mathrm{~mm}$ ) by 3-4 weeks of age. To obtain these animals, we mated heterozygous female Akita mice with WT C57BL/6/J male mice, and the offspring were genotyped by PCR using a forward primer ( $5^{\prime}$-TGCTGATGCCCTGGCCTGCT- $\left.3^{\prime}\right)$ and a reverse primer (5'-TGGTCCCACATATGCACATG-3') to amplify a 280 bp PCR product of the Ins 2 gene. WT mice were identified by digesting the amplified 280 bp fragment with the restriction enzyme Fnu4HI; the Fnu4HI restriction site is absent in the mutant, Akita Ins2 gene. Age-matched male littermates served as control.

STZ injections. Some WT C57BL/6/J $\times$ CD1 mice were made diabetic (blood glucose $>20 \mathrm{~mm}$ ) with STZ. Three- to 4-week-old mice were injected intraperitoneally with 40-60 mg/kg STZ dissolved in $\mathrm{Na}^{+}$citrate buffer. Before these injections, the mice were deprived of food for $6 \mathrm{~h}$, and then food was returned immediately after the injection. Blood glucose levels were monitored at regular intervals with Bayer Contour glucose test strips. Within $48 \mathrm{~h}$ of STZ injection, blood glucose levels were $>20 \mathrm{~mm}$ in $\sim 80 \%$ of mice and remained elevated. Non-injected agematched littermates served as control.

Results obtained from both models were not statistically different from each other. Therefore, in some experiments, we pooled the results from male Akita mice with those from mice made hyperglycemic (blood glucose $>20 \mathrm{~mm}$ ) with STZ.

\section{Primary cultures}

To determine how hyperglycemia affects functional nAChRs, we examined autonomic neurons and adrenal chromaffin cells in culture. Briefly, SCGs, SMGs, submandibular ganglia (Subm), and adrenal medullae were removed from postnatal day 5 (P5) to P20 male and female mice under sterile conditions, enzymatically dissociated at $37^{\circ} \mathrm{C}$ in HBSS containing trypsin ( $1 \mathrm{mg} / \mathrm{ml}$; Worthington), and buffered with HEPES (adjusted to pH 7.4 with $\mathrm{NaOH}$ ). For adrenal medullae, we used $\mathrm{Ca}^{2+}$ - and $\mathrm{Mg}^{2+}$-free HBSS. The resulting cell suspension was washed twice in serum-containing medium and plated on laminin-coated coverslips attached to modified $35 \mathrm{~mm}$ culture dishes (Campanucci et al., 2008). Sympathetic neurons were grown in media consisting of L-15 supplemented with $5 \mathrm{~mm}$ glucose, vitamins, cofactors, penicillin-streptomycin, $5 \%$ rat serum, and $25 \mathrm{ng} / \mathrm{ml}$ nerve growth factor (NGF). Adrenal chromaffin cells were grown in the same media, except without NGF. For parasympathetic neurons, we supplemented the growth media with ciliary-derived neurotrophic factor, glia-derived neurotrophic factor, and neurturin, all at $10 \mathrm{ng} / \mathrm{ml}$. To reduce the growth of non-neuronal cells, cultures were treated with cytosine arabinoside (10 $\mu \mathrm{m}$; Sigma) for the first $48 \mathrm{~h}$ after plating. Cultures were maintained at $37^{\circ} \mathrm{C}$ in an incubator with humidified atmosphere of $95 \%$ air and $5 \% \mathrm{CO}_{2}$, and fresh growth media were added every $3-4 \mathrm{~d}$. To investigate the effects of hyperglycemia, we elevated glucose in the media from 5 to $25 \mathrm{~mm}$.

\section{Synaptic transmission in intact ganglia and adrenal medullae}

We measured synaptic transmission in autonomic ganglia and the adrenal medullae by recording nerve-evoked EPSPs with intracellular electrodes while stimulating the preganglionic nerve. The ganglia or the adrenal medullae were pinned down to the Sylgard floor (Dow Corning) of a recording chamber ( $1.5 \mathrm{ml}$ volume) that was mounted on a fixed stage of a dissecting microscope (SMZ-10; Nikon). The chamber was perfused continuously at $3-4 \mathrm{ml} / \mathrm{min}$ with a modified oxygenated Tyrode's $\left(2.5 \mathrm{mM} \mathrm{Ca}^{2+}\right)$ solution at $33-36^{\circ} \mathrm{C}$. We used $50-70 \mathrm{M} \Omega$ glass microelectrodes (G150F-4; Warner Instruments) made with a DMZ universal puller (Zeitz Instruments) as described previously (Rassadi et al., 2005). To get stable recordings, we used a high inertial precision microdrive (Inchworm 8200; EXFO) attached to a micromanipulator (SM11; Narshige) that drove the electrode through the ganglia or the medulla. The recording electrode was filled with $1 \mathrm{~m}$ KAc and connected by a thin silver chloride wire to the head stage of an Axoclamp 2A amplifier (Molecular Devices) used in current-clamp mode. For each ganglion and the adrenal medulla, the preganglionic nerve (sympathetic trunk for the SCG; left splanchnic nerve for the SMG; the splanchnic nerve for the adrenal medulla; the lingual nerve for the Subm) was connected to a stimulator with a suction electrode and stimulated with brief (0.1-0.3 $\mathrm{ms}$ ) voltage pulses. To quantify synaptic transmission, we stimulated the preganglionic nerve at $0.5-1 \mathrm{~Hz}$ and integrated individual EPSPs. For suprathreshold EPSPs, we integrated the area bound by the spike and then subtracted it from the total area; the area under the action potential was usually $<2 \%$ of the total area. We only recorded from neurons with membrane potentials greater than $-45 \mathrm{mV}$ and held the neurons at -80 to $-85 \mathrm{mV}$ to minimize any afterhyperpolarizations. Data acquisition was done using Igor software (WaveMetrics), and data were analyzed offline. To elevate ROS in some intracellular recordings, we added antimycin-A (anti-A; $100 \mu \mathrm{M}$; Sigma) to the recording electrode solution (a 1:100 dilution from a $10 \mathrm{~mm}$ stock dissolved in EtOH); as control, we recorded from neurons in identical solution $(1 \% \mathrm{EtOH})$ without anti-A.

\section{Whole-cell recordings}

ACh-evoked currents were measured with whole-cell patch clamp as described previously (Campanucci et al., 2008). Membrane currents were recorded with a VE-2 amplifier (Alembic Instruments) at room temperature and were filtered and analyzed offline with Igor software. Recording electrodes were filled with a solution containing the following (in mM): $65 \mathrm{KF}, 55 \mathrm{KAc}, 5 \mathrm{NaCl}, 0.2 \mathrm{CaCl}_{2}, 1 \mathrm{MgCl}_{2}, 10 \mathrm{EGTA}$, and 10 HEPES, pH adjusted to 7.2 with $\mathrm{KOH}$. The electrodes had resistances of $2-5 \mathrm{M} \Omega$, and the series resistance was reduced by $85-100 \%$. The cultures were perfused continuously at $1 \mathrm{ml} / \mathrm{min}$ with a solution containing the following (in mM): $140 \mathrm{NaCl}, 5.4 \mathrm{KCl}, 0.33 \mathrm{NaH}_{2} \mathrm{PO}_{4}, 0.44 \mathrm{KH}_{2} \mathrm{PO}_{4}, 2.8$ $\mathrm{CaCl}_{2}, 0.18 \mathrm{MgCl}_{2}, 10$ HEPES, 5.6 glucose, and 2 glutamine, $\mathrm{pH}$ adjusted to 7.4 with $\mathrm{NaOH}$. ACh $(100 \mu \mathrm{M})$ was dissolved in the perfusion solution and applied to neurons by pressure ejection from pipettes with tip diameters of $2-5 \mu \mathrm{m}$ positioned $20-30 \mu \mathrm{m}$ from the cell body (Campanucci et al., 2008). To increase cytosolic ROS in individual neurons, we dissolved 

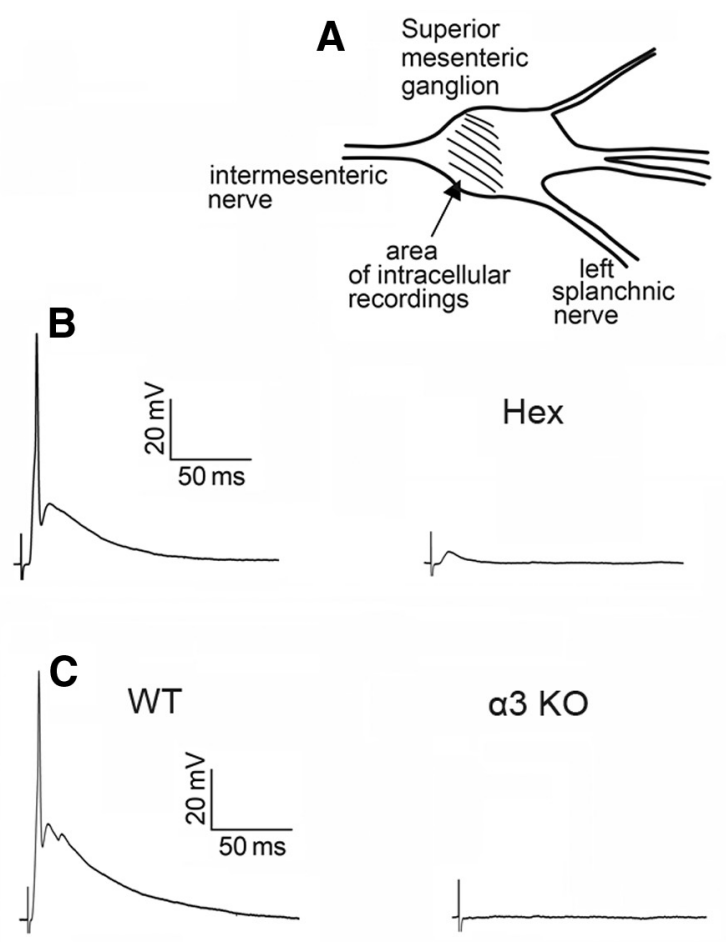

a3 KO

D Control
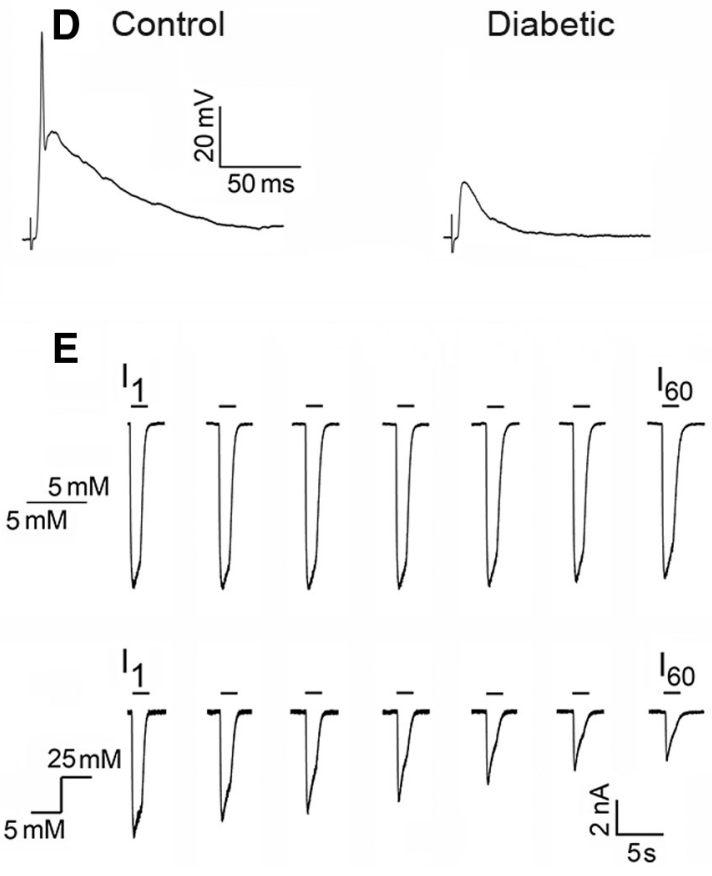

Figure 1. Synaptic transmission in sympathetic SMGs is mediated by $\alpha 3$-containing nAChRs and becomes depressed in diabetes. $\boldsymbol{A}$, A schematic of the SMG showing the region of the ganglion used for recording. $\boldsymbol{B}$, Left, Nerve-evoked EPSPs in SMGs in response to splanchnic nerve stimulation. Middle, Response in Hex $(100 \mu \mathrm{m})$. Right, Response after washing out Hex. $\boldsymbol{C}$, Left, Nerve-evoked EPSPs in SMGs from 1 month-old WT and $\alpha 3$ KO age-matched mice. Right, Average integrated EPSP size in SMGs of WT $(n=60 ; 3$ mice $)$ and $\alpha 3 \mathrm{KO}\left(n=31 ; 3\right.$ mice). The values are means \pm SEM $.^{*} p<0.0001 . D$, Left, Nerve-evoked EPSPs in SMGs of 2 month-old WT control and 2-month-old Akita mice ( 5 weeks after the onset of diabetes). Right, Average integrated EPSPs in SMGs from 1 week ( $n=94 ; 4$ mice) and 1 month ( $n=70 ; 4$ mice) after the onset of diabetes; the data are percentage of EPSPs in SMGs of age-matched WT controls [ $n=60$ for 1 week ( 3 mice); $n=16$ for 1 month ( 3 mice)]. The data from diabetic mice include both Akita mice and WT mice made diabetic with STZ injections. $n=60$ for age-matched control SMG neurons to compare with those in mice that were diabetic for 1 week, and $n=16$ to compare with those in mice diabetic for 1 month. The values are the mean \pm SEM and are significantly different from age-matched controls $\left({ }^{*} p<0.0001\right)$. $\boldsymbol{E}$, Elevated $(25 \mathrm{~mm})$ extracellular glucose causes rundown of ACh-evoked inward currents on cultured SMG neurons. Left, ACh-evoked currents on cultured SMG neurons in response to $1 \mathrm{~s}$ application of $\mathrm{ACh}(100 \mu \mathrm{m})$ delivered at $15 \mathrm{~s}$ intervals. Top, Cultured in $5 \mathrm{~mm}$ glucose for 2 weeks.
anti-A in the recording solution at 1,2 , and 10 $\mu \mathrm{M}(1: 10,000,2: 10,000$, and $1: 1000$ dilutions, respectively, from a $10 \mathrm{~mm}$ stock solution dissolved in $\mathrm{EtOH}$ ). As control, we used an identical solution $(0.01,0.02$, and $0.1 \% \mathrm{EtOH})$ without anti-A. As a measure of rundown of the ACh-evoked currents, we plotted the ratio of the peak current $(I)$ in response to the 30th $\left(I_{30}\right)$ or 60 th $\left(I_{60}\right)$ application to the first application $\left(I_{1}\right)$ in the series.

\section{Intracellular ROS measurements}

To monitor ROS levels, we loaded cultures with the redox-sensitive dye $\mathrm{CM}-\mathrm{H}_{2} \mathrm{DCFDA}$ (chloromethyl derivative of $2^{\prime}, 7^{\prime}$-dichlorodihydrofluorescein diacetate), an acetoxymethyl ester (Invitrogen), which was dissolved in perfusion solution at $10 \mu \mathrm{M}$. The cultures were incubated for $30 \mathrm{~min}$ at $37^{\circ} \mathrm{C}$ and then washed three times with recording perfusion solution. The cultures were then placed on the stage of an inverted microscope (Axiovert 200M; Zeiss) and viewed though a $40 \times(1.3$ numerical aperture) Plan Neofluor oil-immersion objective (Zeiss). The cells were perfused continuously, and whole-cell recordings were done as described above. For simultaneous ROS measurements, we acquired differential interference contrast (DIC) and fluorescent images (Campanucci et al., 2008). We excited the dye at wavelengths of $450-$ $480 \mathrm{~nm}$ for $200 \mathrm{~ms}$ using a $150 \mathrm{~W}$ xenon arc lamp (LAMBDA DG-4; Sutter Instruments), and the signal was detected at an emission wavelength of $510-550 \mathrm{~nm}$ (filter set 31001; Chroma Technology) with a cooled CCD camera (CoolSnap HQ; PhotoMetrics) controlled by Metafluor software (Universal Imaging). On the DIC images, we defined regions of interest (neuronal cell body, excluding the nucleus) and transferred these to the fluorescent images of the same field. We quantified changes in mean $\mathrm{CM}-\mathrm{H}_{2}$ DCFDA fluorescence intensity over time by acquiring images every $25 \mathrm{~s}$. The background fluorescence was determined from the neighboring area. For each neuron, we subtracted its initial fluorescent intensity $(F)$ from the final fluorescent intensity to obtain the change in fluorescent intensity $(\Delta F)$ and expressed it as $\Delta F / F$.

\section{Statistics}

For differences in the mean fluorescent intensities, we used the Student's $t$ test; for comparisons of the $I_{30} / I_{1}$ or $I_{60} / I_{1}$ ratios or EPSP areas, we used the nonparametric Mann-Whitney $U$ test.

All procedures for animal handling were performed according to the guidelines of the Canadian Council on Animal Care.

Bottom, Cultured in 5 mm glucose for the first week and then in 25 $\mathrm{mm}$ glucose for the second week. Every fifth trace is shown for clarity. Right, $I_{60} / I_{1}$ for neurons cultured in $5 \mathrm{~mm}$ glucose for 2 weeks $(n=21)$ and for neurons cultured in $5 \mathrm{~mm}$ glucose for the first week and then in $25 \mathrm{~mm}$ glucosefor the second week $(n=15)$. The values are the mean \pm SEM. ${ }^{*} p<0.0001$. Ctrl, Control. 


\section{Results}

SMG

To investigate the effects of type 1 diabetes on synaptic transmission in the SMG, we recorded with intracellular electrodes from SMG neurons of 1- to 2-month-old mice while stimulating the left splanchnic nerve. Some neurons in the anterior part of the ganglion send axons out through the splanchnic nerve and become excited antidromically (Miller et al. 1996). To avoid this, we recorded mainly from neurons located in the posterior part of the ganglion (Fig. 1A). Stimulating the splanchnic nerve evoked large, suprathreshold fast EPSPs on SMG neurons; these EPSPs were reversibly blocked by hexamethonium (Hex; $100 \mu \mathrm{M})$, indicating that these synapses were cholinergic-nicotinic (Fig. 1B). To determine whether these EPSPs were mediated by $\alpha 3$-containing nAChRs, we recorded from SMGs of $\alpha 3 \mathrm{KO}$ mice (Xu et al., 1999; Rassadi et al., 2005; Krishnaswamy and Cooper, 2009). The EPSPs evoked by splanchnic nerve stimulation were $<5 \%$ of control on $>95 \%$ of the neurons ( 43 of 45 ; Fig. 1C), and on most (75\%), the EPSPs were not detectable; these results indicate that the EPSPs on SMG neurons are mediated by $\alpha 3$-containing nAChRs.

Next, we investigated synaptic transmission in SMGs from Akita mice or from mice made diabetic with STZ injection, 1 week and 1 month after the onset of hyperglycemia (blood glucose $>20 \mathrm{~mm}$ ). We found that EPSPs were markedly reduced on SMG neurons from diabetic mice compared with those in age-matched control mice (Fig. 1D). On average, the EPSPs were depressed by $\sim 65 \% 1$ week after onset of diabetes, and this depression persisted for at least 1 month (Fig. 1D).

The results in Figure $1 D$ show that diabetes depresses synaptic transmission at synapses on prevertebral SMG neurons. Next, we asked whether hyperglycemia leads to an inactivation of the postsynaptic nAChRs on these neurons, as is the case for sympathetic neurons in the paravertebral SCG (Campanucci et al., 2010). To address this, we recorded ACh-evoked inward currents on SMG neurons that developed in culture under hyperglycemic conditions. Neurons from 2- to 3-weekold mice were cultured for $7 \mathrm{~d}$ in $5 \mathrm{~mm}$ glucose, and then glucose was elevated to $25 \mathrm{~mm}$ for $7 \mathrm{~d}$; the controls were maintained in $5 \mathrm{~mm}$ glucose throughout the $14 \mathrm{~d}$ period. A single application of ACh (100 $\mu \mathrm{M}$ applied for $1 \mathrm{~s}$ ) evoked large
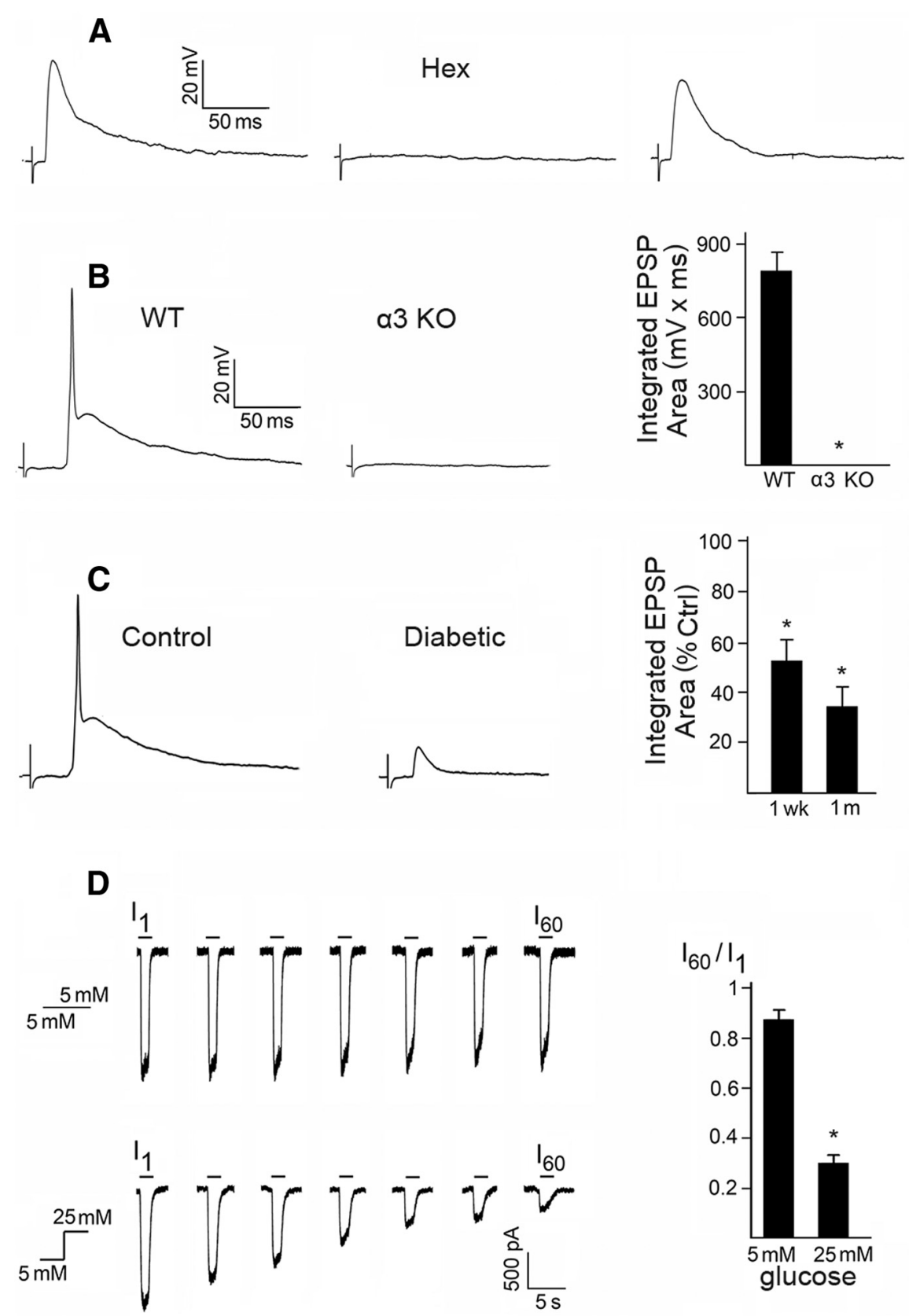

Figure 2. Synaptic transmission in adrenal medulla is mediated by $\alpha 3$-containing $n A C h R s$ and becomes depressed in diabetes. $\boldsymbol{A}$, Left, Nerve-evoked EPSPs recorded intracellularly in adrenal medulla in response to splanchnic nerve stimulation. Middle, Response in Hex (100 $\mu \mathrm{m})$. Right, Response after washing out Hex. $\boldsymbol{B}$, Left, Nerve-evoked EPSPs at synapses on WT and $\alpha 3 \mathrm{KO}$ adrenal chromaffin cells. Right, Average integrated EPSPs on chromaffin cells in adrenals from WT ( $n=$ 26; 6 mice) and $\alpha 3 \mathrm{KO}$ ( $n=10 ; 3$ mice). The values are means \pm SEM. ${ }^{*} p<0.0001$. C, Left, Nerve-evoked EPSPs at synapses on a chromaffin cell from a 1-month-old WT mouse and from age-matched diabetic (Akita) mice. Right, Average integrated EPSPs at synapses on chromaffin cells from mice 1 week $(n=50 ; 10$ mice) and 1 month ( $n=21 ; 4$ mice) after the onset of diabetes; the data are expressed as a percentage of EPSPs at synapses on chromaffin cells from age-matched WT mice. The data from diabetic mice include both Akita mice and WT mice made diabetic with STZ injections. $n=45$ (6 mice) for age-matched control chromaffin cells to compare with those in mice that were diabetic for 1 week, and $n=27$ (7 mice) to compare with those in mice diabetic for 1 month. The values are the mean \pm SEM. ${ }^{*} p<0.0001$. D, Elevated (25 mm) extracellular glucose causes rundown of ACh-evoked inward currents on cultured chromaffin cells. Left, AChevoked currents on cultured adrenal chromaffin cells in response to $1 \mathrm{~s}$ application of ACh (100 $\mu \mathrm{m})$ delivered at $15 \mathrm{~s}$ intervals. Top, Cultured in $5 \mathrm{~mm}$ glucose for 2 weeks. Bottom, Cultured in $5 \mathrm{~mm}$ glucose for the first week and then in $25 \mathrm{~mm}$ glucose for the second week. Every fifth trace is shown for clarity. Right, $I_{60} / I_{1}$ for neurons cultured in $5 \mathrm{~mm}$ glucose for 2 weeks $(n=10)$ and for neurons cultured in $5 \mathrm{~mm}$ glucose for the first week and then in $25 \mathrm{~mm}$ glucose for the second week $(n=11)$. The values are the mean \pm SEM. ${ }^{*} p<0.0001$. Ctrl, Control. 

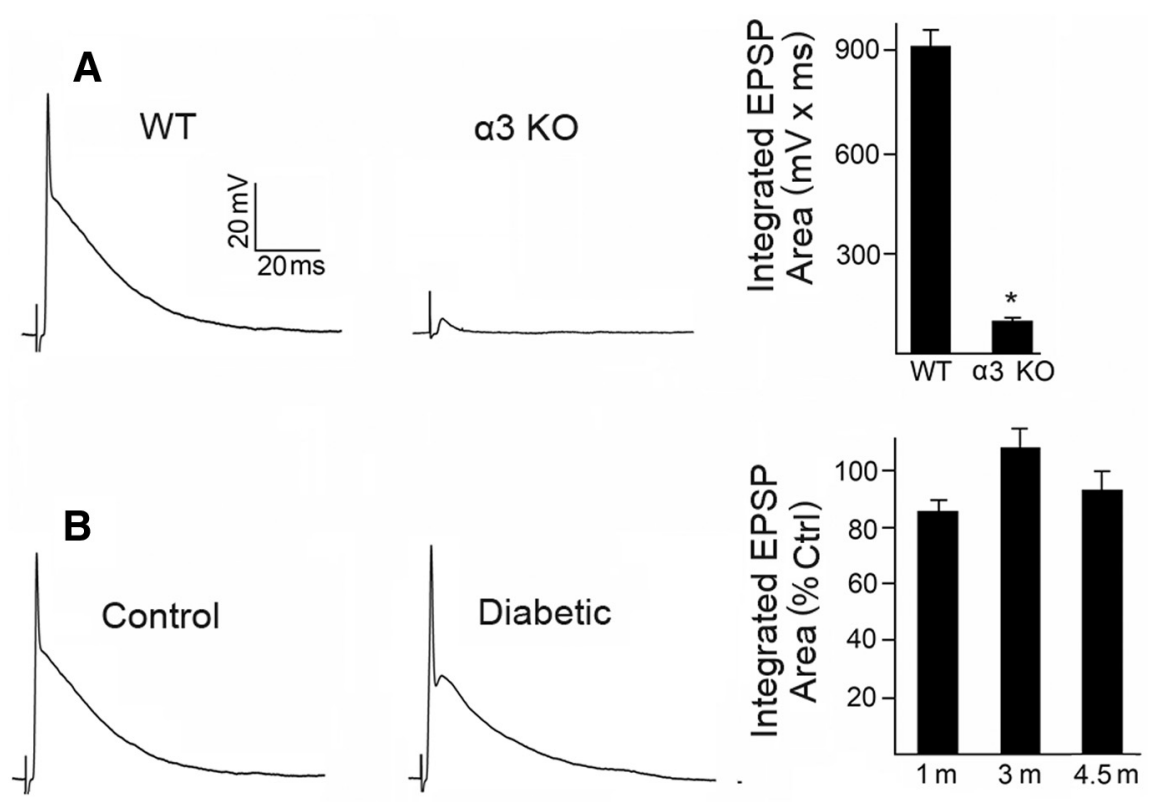

Figure 3. Synaptic transmission in parasympathetic Subms is mediated mainly by $\alpha 3$-containing $n A C h R s$ and is not affected by diabetes. $\boldsymbol{A}$, Left, Nerve-evoked EPSPs at synapses on WT and $\alpha 3 \mathrm{KO}$ Subm neurons in response to the preganglionic nerve stimulation. Right, Average integrated EPSPs on Subm neurons in intact ganglia from WT ( $n=40 ; 4$ mice) and $\alpha 3 \mathrm{KO}(n=55 ; 3$ mice) mice. The values are means \pm SEM. ${ }^{*} p<0.0001$. B, Left, Nerve-evoked EPSPs in Subms of 2-month-old WT control and 2-month-old Akita mice (5 weeks after the onset of diabetes). Right, Average integrated EPSPs in Subms from 1 month ( $n=52$; 4 mice), 3 months ( $n=57 ; 3$ mice), and 4.5 months ( $n=32 ; 3$ mice) after the onset of diabetes. The data are percentage of EPSPs in Subms of age-matched WT control [ $n=40$ ( 4 mice) for 1 month, $n=9$ ( 3 mice) for 3 months, and $n=26$ (3 mice) for 4.5 months]. The data from the diabetic mice include both Akita mice and WT mice made diabetic with STZ injection. The values are the mean \pm SEM; $p=0.02$ at 1 month; $p>0.05$ at 3 and 4.5 months. Ctrl, Control.

$(\sim 5-7 \mathrm{nA})$ inward currents when measured at a holding potential of $-60 \mathrm{mV}$ (Fig. 1E). On control neurons (neurons cultured in $5 \mathrm{~mm}$ glucose for $14 \mathrm{~d}$ ), these ACh-evoked currents were stable in response to a series of repetitive ACh applications at $15 \mathrm{~s}$ intervals (Fig. 1E). In contrast, we observed an irreversible rundown of the ACh-evoked currents on neurons cultured in $25 \mathrm{~mm}$ glucose; after 30 applications, the peak $I_{\mathrm{ACh}}$ was $\sim 50 \%$ of the first application and reached a plateau of $\sim 35 \%$ after $50-60$ applications (Fig. 1E). These results indicate that hyperglycemia causes a use-dependent rundown of the ACh-evoked currents on prevertebral SMG neurons, similar to what it does on paravertebral sympathetic neurons in the SCGs (Campanucci et al., 2010).

\section{Adrenal medulla}

Next, we investigated the effects of diabetes on synaptic transmission at synapses on chromaffin cells in intact adrenal medulla. Stimulating the greater splanchnic nerve evoked large, cholinergic-nicotinic EPSPs on chromaffin cells, recorded intracellularly, that were reversibly blocked by Hex (100 $\mu$ M; Fig. 2A). These EPSPs were large enough to evoke action potentials on $\sim 50 \%$ of the chromaffin cells ( 27 of 52 ). If these EPSPs are mediated by $\alpha 3$-containing nAChRs, then they could be targets of elevated ROS; however, the subtype of nAChRs present postsynaptically at synapses between preganglionic terminals and chromaffin cells had not been fully established. Therefore, to determine whether the nerve-evoked EPSPs are mediated by $\alpha 3$ containing nAChRs, we recorded nerve-evoked EPSPs on chromaffin cells in intact adrenal medulla from $\alpha 3 \mathrm{KO}$ mice. In contrast to WT adrenal medullae, stimulating the greater splanchnic nerve innervating adrenal medullae from 1-monthold $\alpha 3 \mathrm{KO}$ mice failed to evoke EPSPs on chromaffin cells ( $n=$
56), although all chromaffin cells evoked action potentials when stimulated directly. These results indicate that $\alpha 3$ containing nAChRs are the major postsynaptic receptors at preganglionicchromaffin synapses in mice.

To determine whether diabetes depresses synaptic transmission in the adrenal medulla, we recorded nerve-evoked EPSPs on chromaffin cells 1 week and 1 month after the onset of diabetes. Within 1 week after the onset of diabetes, the nerve-evoked EPSPs were depressed by $\sim 50 \%$ compared with those in agematched control mice (Fig. 2C), and this depression persisted for at least 1 month (Fig. 2C).

The results in Figure $2 C$ show that diabetes induces a depression in synaptic transmission at synapses on adrenal chromaffin cells. To determine whether hyperglycemia inactivates the postsynaptic nAChRs on these cells, we recorded AChevoked inward currents on chromaffin cells that developed in culture initially in 5 mu glucose for $7 \mathrm{~d}$ and then switched to $25 \mathrm{~mm}$ glucose for $7 \mathrm{~d}$; as control, we recorded from chromaffin cells that were cultured in $5 \mathrm{~mm}$ glucose throughout the $14 \mathrm{~d}$ period.

ACh applications $(100 \mu \mathrm{M}$ for $1 \mathrm{~s})$ evoked large $(\sim 1-3 \mathrm{nA})$ inward currents when measured at a holding potential of $-60 \mathrm{mV}$ (Fig. 2D). On chromaffin cells in control media ( $5 \mathrm{~mm}$ glucose for $14 \mathrm{~d}$ ), these ACh-evoked currents were stable in response to a series of repetitive ACh $(100 \mu \mathrm{M})$ applications at $15 \mathrm{~s}$ intervals (Fig. 2D). In contrast, we observed an irreversible rundown of the AChevoked currents on chromaffin cells cultured in $25 \mathrm{~mm}$ glucose for $7 \mathrm{~d}$ (Fig. 2D); after the 30th application, the peak $I_{\mathrm{ACh}}$ was $\sim 50 \%$ of the first application and reached a plateau of $\sim 25 \%$ after 50-60 applications. These results indicate that hyperglycemia causes a use-dependent rundown of ACh-evoked currents on adrenal chromaffin cells, similar to its effects on the ACh currents on sympathetic neurons in both paravertebral SCGs and prevertebral SMGs.

\section{Parasympathetic neurons}

Synaptic transmission in ganglia throughout the autonomic nervous system is mediated by cholinergic-nicotinic synapses. Therefore, we had expected that diabetes would similarly depress synaptic transmission in parasympathetic ganglia, as it does in sympathetic ganglia and the adrenal medulla. To test this idea, we recorded intracellularly from parasympathetic neurons in intact Subm of 1- to 2-month-old mice while stimulating the preganglionic lingual nerve. As expected, stimulating the lingual nerve evoked large, suprathreshold fast EPSPs on submandibular neurons; these EPSPs were reversibly blocked by Hex $(100 \mu \mathrm{M})$, indicating that these synapses were cholinergic-nicotinic.

To determine whether these EPSPs are mediated by $\alpha 3$ containing nAChRs, we recorded nerve-evoked responses on Subm neurons from $\alpha 3 \mathrm{KO}$ mice (Fig. $3 A$ ). More than $\sim 75 \%$ ( $n=46$ of 64) of neurons in $\alpha 3$ KO Subms had no detectable nerve-evoked responses; for the remaining $\sim 20 \%$ (14 of 64 ), 
A
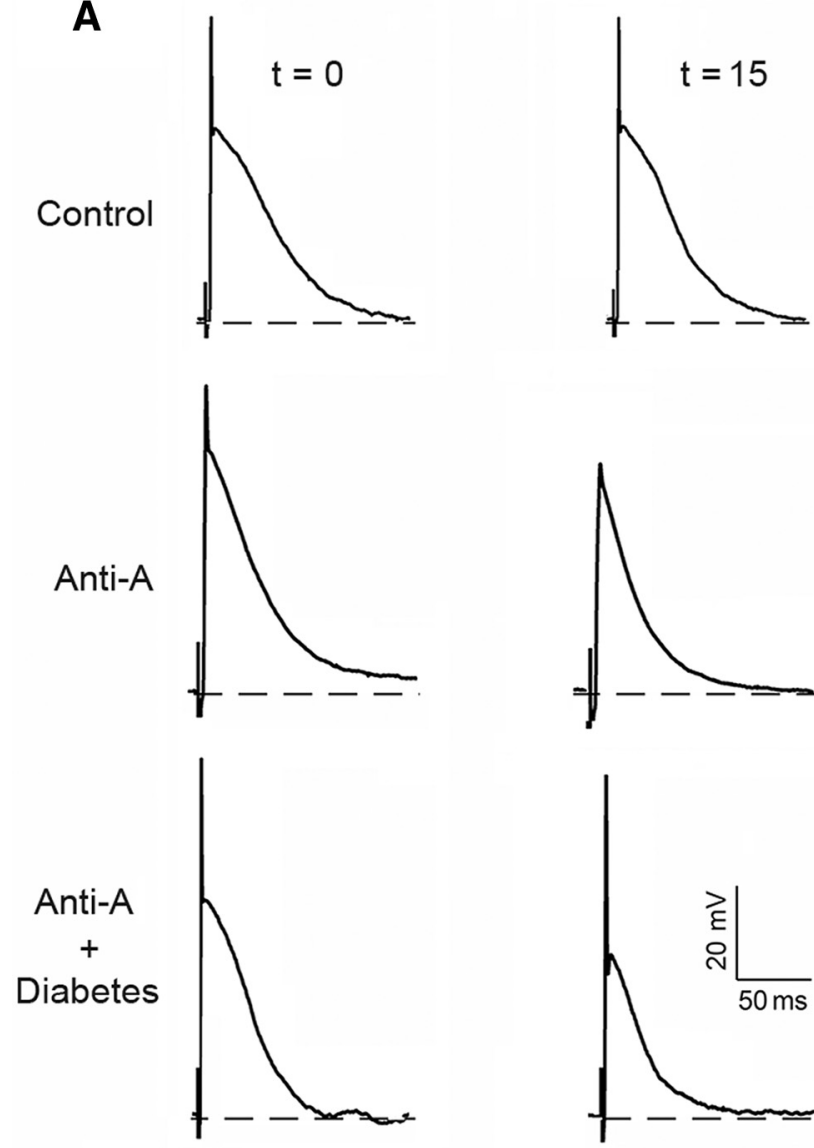

preganglionic nerve stimulation evoked small 2-4 mV EPSPs. These data indicate that the nerve-evoked EPSPs on $>90 \%$ of parasympathetic submandibular neurons are mediated almost exclusively by $\alpha 3$-containing nAChRs (Fig. 3A). In a small number of $\alpha 3$ KO neurons ( $n=4$ of 64), the nerve-evoked EPSPs were $>10 \mathrm{mV}$ and possibly mediated by $\alpha 7$-containing nAChRs.

To establish whether diabetes depresses synaptic transmission in parasympathetic ganglia, we recorded nerve-evoked EPSPs on neurons in Subms, 5 weeks after the onset of diabetes. In contrast to what we observed in sympathetic ganglia and the adrenal medulla, we found no statistical difference between nerve-evoked EPSPs on parasympathetic neurons from diabetic animals compared with those on age-matched controls (Fig. 3B). To determine whether parasympathetic neurons require longer exposure to hyperglycemia before synaptic transmission becomes depressed, we recorded synaptic transmission in Subms from diabetic mice up to 4.5 months after the onset of diabetes. Yet, even after 4.5 months of diabetes, the nerve-evoked EPSPs at synapses on parasympathetic neurons were no different statistically from those on age-matched controls (Fig. 3B). These unexpected results indicate that synaptic transmission on parasympathetic neurons is less sensitive to diabetes compared with that at synapses on sympathetic neurons or adrenal chromaffin cells.

The results in Figure 3 suggest that hyperglycemia does not elevate ROS in parasympathetic neurons as it does in sympathetic neurons, and consequently, the postsynaptic, $\alpha 3$-containing nAChRs on parasympathetic neurons are not inactivated by hyperglycemia. Equally possible, $\alpha 3$-containing nAChRs on parasympathetic neurons are somehow different from those on sympathetic neurons and do not become inactivated by elevations in cytosolic ROS.

To examine the first possibility, we injected parasympathetic neurons through the recording electrode with anti-A, a drug known to increase ROS production by blocking complex III of the mitochondrial electron transport chain (ETC). We chose this approach because previous work showed that similar treatment when recording from SCGs depresses the nerve-evoked EPSPs by $\sim 50 \%$ (Campanucci et al., 2008). Unlike synapses on sympathetic neurons, however, the nerve-evoked EPSPs were depressed by $<10 \%$ when recording from parasympathetic neurons with anti-A-containing electrodes (Fig. 4A,B). This lack of effect with anti-A suggests that parasympathetic neurons may be more effective at buffering ROS than sympathetic neurons.

Next, we asked whether pairing hyperglycemia with anti-A might elevate ROS sufficiently to depress synaptic transmission. Interestingly, we found that the nerve-evoked EPSPs were depressed by $>30 \%$ when we recorded from parasympathetic neurons from diabetic mice with anti-A in the electrode (Fig. 4A,B), a greater depression than either treatment alone. This result suggests that a partial block of complex III in parasympathetic neurons, when coupled with hyperglycemia, will produce a sufficient elevation in cytosolic ROS to inactivate the postsynaptic nAChRs.

\section{Elevating ROS in parasympathetic neurons inactivates $\alpha 3$ - containing nAChRs}

To test directly whether elevating cytosolic ROS in parasympathetic neurons causes a use-dependent inactivation of nAChRs, we planned to examine isolated neonatal mouse parasympathetic neurons in culture. However, we could find no previous reports on the growth of mammalian parasympathetic neurons in longterm culture; therefore, before we could perform these experiments, we needed to establish the appropriate growth condition for dissociated parasympathetic neurons (see Materials and 
A

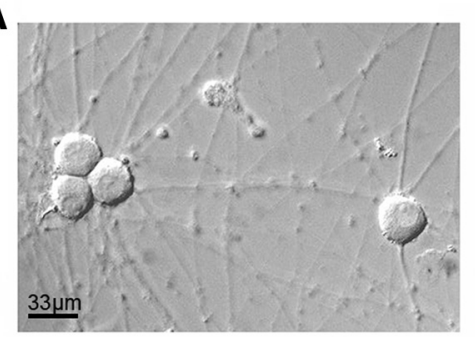

B
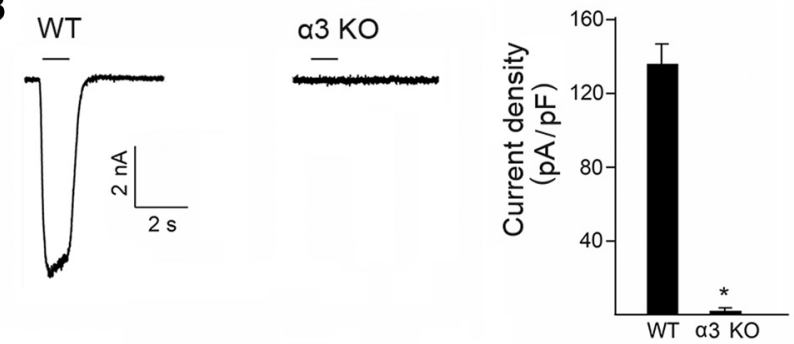

C

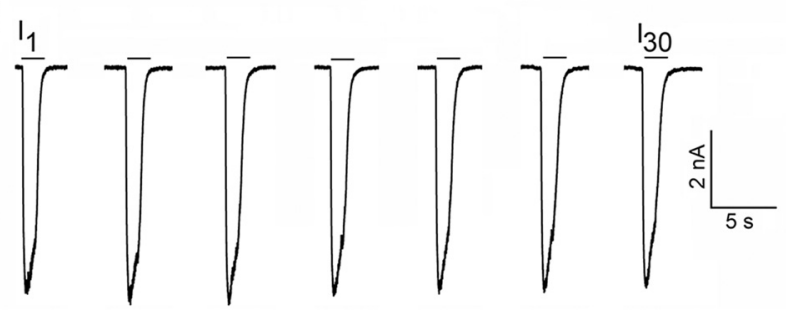

Figure 5. Cultured submandibular neurons have stable ACh-evoked inward currents mediated by $\alpha 3$-containing nAChRs. $\boldsymbol{A}$, Photomicrograph of dissociated mouse parasympathetic Subm neurons in culture for 2 weeks. $\boldsymbol{B}$, Left, ACh-evoked inward currents on cultured Subm neurons from WT mice in response to a $1 \mathrm{~s}$ application of ACh $(100 \mu \mathrm{M})$. Middle, No ACh-evoked currents on cultured Subm neurons from $\alpha 3 \mathrm{KO}$ mice. Right, Average ACh-evoked currents on cultured parasympathetic neurons from WT $(n=28)$ and $\alpha 3 \mathrm{KO}(n=12)$ mice. The values are the mean \pm SEM. ${ }^{*} p<0.0001$. C, ACh-evoked inward currents on cultured Subm neurons from WT mice in response to a $1 \mathrm{~s}$ applications of $\mathrm{ACh}(80 \mu \mathrm{m})$ at $15 \mathrm{~s}$ intervals. These data show that ACh-evoked currents on cultured parasympathetic neurons are stable.

Methods). Using our procedures, we observed that dissociated neurons from young (P5-P20) mouse Subms grew well in culture for at least 2-3 weeks (Fig. 5A). Relevantly, these cultured parasympathetic neurons have large, stable ACh-evoked inward currents (Fig. 5B), and when ACh $(80-100 \mu \mathrm{M})$ was applied repetitively at $15 \mathrm{~s}$ intervals, we saw no significant decline in the ACh-evoked currents (Fig. 5C). Moreover, we could not detect any response when applying ACh $(100 \mu \mathrm{M})$ on to Subm neurons from $\alpha 3 \mathrm{KO}$ mice (Fig. 5B), indicating that the inward currents on these cultured parasympathetic neurons are mediated by $\alpha 3$ containing nAChRs.

To determine whether elevating cytosolic ROS inactivates nAChRs on parasympathetic neurons, first we loaded neurons with the ROS indicator DCFDA and elevated ROS by including anti-A in the recording electrode during whole-cell recording. Then we simultaneously imaged neurons to monitor changes in ROS-induced fluorescence and recorded whole-cell ACh-evoked currents in voltage clamp. As control, we recorded from neurons in the same microscopic field but without anti-A in the pipette solution.

Including $1 \mu \mathrm{M}$ anti-A in the recording electrode to inhibit partially the ETC complex III failed to produce a significant change in DCFDA fluorescence (Fig. 6A,B). Moreover, the AChevoked inward currents on these neurons were stable in response to repetitive ACh application (Fig. $6 C, D$ ); $I_{30}$ was not significantly different from $I_{1}$ (zfr;6Fig. 6C,D). These results are in contrast to those from sympathetic neurons: we observed an approximate twofold increase in ROS-induced DCFDA fluorescence (Fig. $6 A, B)$ and an irreversible rundown of the ACh-evoked inward currents when recording from sympathetic neurons with $1 \mu \mathrm{M}$ anti-A in the recording electrode (Fig. $6 C, D$ ), similar to what was reported previously (Campanucci et al., 2008).

To determine whether a stronger block of the ETC complex III would elevate cytosolic ROS in parasympathetic neurons, we recorded from Subm neurons with 2 and $10 \mu \mathrm{M}$ anti-A in the recording electrode; $2 \mu \mathrm{M}$ anti-A produced a significant increase in ROS-induced in DCFDA fluorescence, which increased even further with $10 \mu \mathrm{M}$ anti-A (Fig. 6A,B). Moreover, when cytosolic ROS was elevated with $10 \mu \mathrm{M}$ anti-A, repeated application of ACh $(80 \mu \mathrm{M})$ caused the ACh-evoked inward currents to run down; $I_{30}$ was $\sim 40 \%$ of $I_{1}$ (Fig. $6 C, D$ ). These results indicate that an increase in cytosolic ROS in parasympathetic neurons leads to a use-dependent inactivation of nAChRs, as it does on sympathetic neurons.

\section{Sympathetic neurons are more vulnerable to hyperglycemia than parasympathetic neurons}

Our results with partial block of the ETC complex III suggest that parasympathetic neurons differ from sympathetic neurons in their ability to buffer ROS from mitochondria. Moreover, our results from recording nerve-evoked EPSPs in intact ganglia suggest that postsynaptic nAChRs on sympathetic neurons exposed to hyperglycemia are inactivated, whereas those on parasympathetic neurons are stable. To test directly whether hyperglycemia causes a use-dependent rundown of ACh-evoked currents on parasympathetic neurons, we grew parasympathetic neurons from 2- to 3 -week-old mice in culture for $7 \mathrm{~d}$ in $5 \mathrm{~mm}$ glucose, and then glucose was elevated to $25 \mathrm{~mm}$ for $7 \mathrm{~d}$ while keeping the controls in $5 \mathrm{~mm}$ glucose throughout the $14 \mathrm{~d}$ period. For comparison, we grew sympathetic neurons from the SCG under identical conditions. For sympathetic neuron cultures, the steady-state ROSinduced DCFDA fluorescence in neurons in $25 \mathrm{~mm}$ glucose was approximately twofold greater than those in control $5 \mathrm{~mm}$ $(1.87 \pm 0.2$, mean \pm SEM; $n=18)$, whereas, for parasympathetic cultures, the steady-state DCFDA levels in neurons in $25 \mathrm{~mm}$ glucose were not significantly different from those in control 5 $\mathrm{mm}(1.18 \pm 0.2$, mean $\pm \mathrm{SEM} ; n=15)$. Consistent with these ROS-induced DCFDA measurements, the ACh-evoked inward currents on sympathetic neurons maintained in $25 \mathrm{~mm}$ glucose ran down, whereas those on parasympathetic neurons were stable (data not shown). These results on ROS levels and ACh-evoked currents indicate that sympathetic neurons are more vulnerable to hyperglycemia than parasympathetic neurons.

Conversely, in diabetic mice, we found that including anti-A in the recording electrode depressed synaptic transmission at synapses on parasympathetic neurons in diabetic mice (Fig. 4). Therefore, we asked whether anti-A would elevate ROS in parasympathetic neurons when cultured in hyperglycemic conditions. To test this, we included $1 \mu \mathrm{M}$ anti-A while recording from cultured parasympathetic Subm neurons maintained in $25 \mathrm{~mm}$ glucose for 5-7 d. We found a significant 1.5- to 2-fold increase in ROS-induced DCFDA fluorescence compared with control (Fig. $7 A$ ). Equally relevant, the ACh-evoked inward currents on these neurons ran down, whereas those on neighboring neurons recorded without anti-A were stable (Fig. 7B). 
A

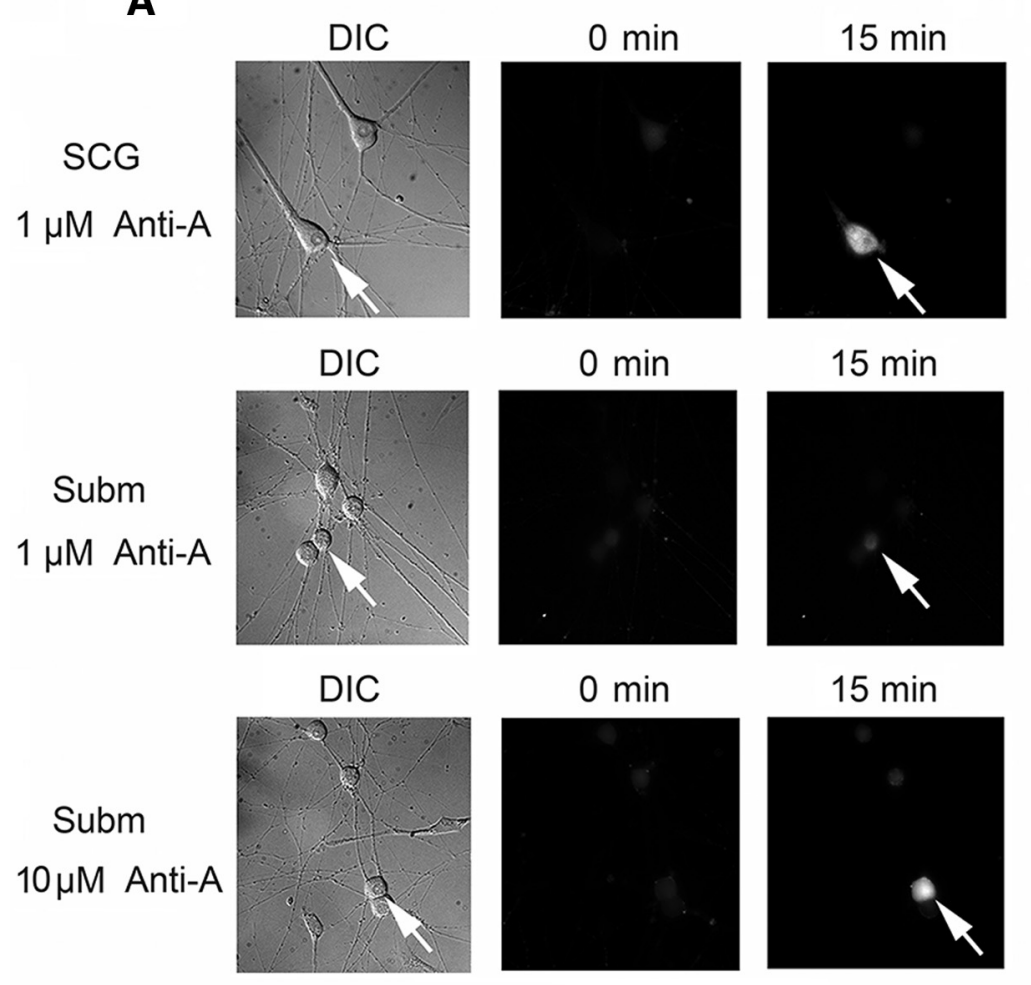

B

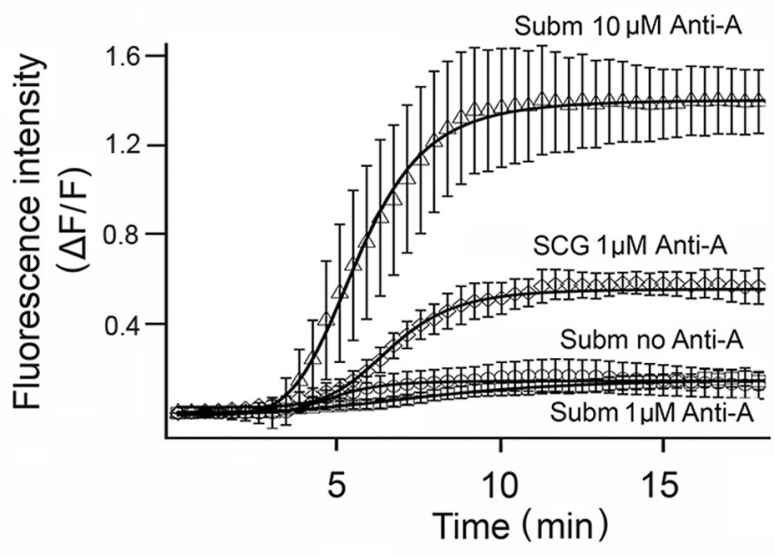

D

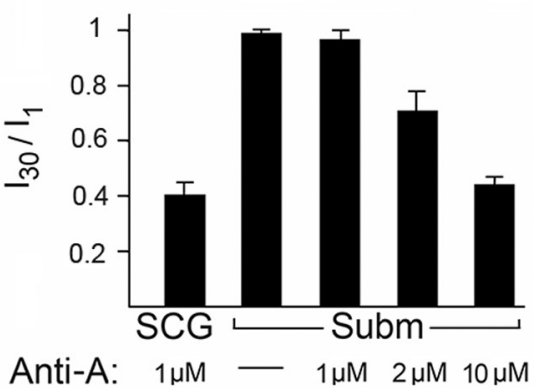

Figure 6. Blocking mitochondrial complex III elevates cytosolic ROS on parasympathetic neurons and inactivates nAChRs. A, DIC (left) and DCFDA-induced fluorescent images (right) of cultured sympathetic (top) and parasympathetic neurons (middle and bottom) immediately or 15 min after perfusing the neurons through the recording electrode with either $1 \mu \mathrm{m}$ anti-A (top and middle) or $10 \mu \mathrm{m}$ anti-A (bottom). Fluorescence intensities were measured at $25 \mathrm{sintervals}$ for a period of $15 \mathrm{~min}$. In all experiments, neurons were preloaded with $\mathrm{CM}-\mathrm{H}_{2} \mathrm{DCFDA}$ for $30 \mathrm{~min}$ and treated acutely with anti-A through the recording electrode. $\boldsymbol{B}$, Average increases in ROS-induced DCFDA fluorescence for sympathetic SCG neurons $(n=6)$ perfused intracellularly through the

\section{Discussion}

To learn more about diabetes-induced dysautonomia, we focused on synaptic transmission in autonomic ganglia. The activity of cholinergic-nicotinic synapses in autonomic ganglia represents the final output of various CNS structures that regulate autonomic function; when synaptic transmission in autonomic ganglia is depressed, dysautonomia ensue. Previous work demonstrated that hyperglycemia, produced by either type 1 or type 2 diabetes, depresses synaptic transmission in SCGs by causing an ROS-dependent inactivation of the postsynaptic nAChRs (Campanucci et al., 2010). This inactivation involves the highly conserved Cys residues on the $\alpha 3$ nAChR subunit located near the intracellular mouth of receptors (Campanucci et al., 2010; Krishnaswamy and Cooper, 2012).

In this study, we demonstrate that sympathetic and parasympathetic ganglia differ in their vulnerability to diabetes. Hyperglycemia depresses synaptic transmission in prevertebral and paravertebral sympathetic ganglia and in the adrenal medulla, but surprisingly hyperglycemia has relatively little effect on synaptic transmission in parasympathetic ganglia, even though synaptic transmission in both types of ganglia and in the adrenal medulla is mediated by $\alpha 3$-containing nAChRs. In line with our findings, it was reported recently that hyperglycemia does not depress synaptic transmission on parasympathetic neurons in the pelvic ganglia (Tompkins et al., 2013).

It seems unlikely that differences in postsynaptic nAChRs are responsible for the differential vulnerability of ganglia to hyperglycemia. Although the precise sub-

\section{$\leftarrow$}

recording electrode with $1 \mu \mathrm{m}$ anti-A and parasympathetic neurons perfused without anti-A $(n=6), 1 \mu \mathrm{m}$ anti-A $(n=$ $16)$, or $10 \mu \mathrm{m}$ anti-A $(n=21)$. The data represent the mean $\Delta F / F \pm$ SEM and fit with a Hill function (solid lines). For Subm neurons ( $1 \mu \mathrm{m}$ anti-A) versus $S C G$ neurons $(1 \mu \mathrm{m}$ anti-A) and for Subm neurons (1 $\mu \mathrm{m}$ anti-A) versus Subm neurons (10 $\mu \mathrm{m}$ anti-A), $p<0.001$; for Subm neurons (no anti-A) versus Subm neurons ( $1 \mu \mathrm{m}$ anti-A), $p>0.2$. C, ACh-evoked inward currents on cultured parasympathetic neurons from WT mice in response to a $1 \mathrm{~s}$ application of $\mathrm{ACh}(80 \mu \mathrm{m})$ at $15 \mathrm{~s}$ intervals $\sim 15$ min after perfusing neurons intracellularly with either 1 $\mu \mathrm{m}$ anti-A (top) or $10 \mu \mathrm{m}$ anti-A (bottom). Every fifth trace is shown for clarity. $\boldsymbol{D}, I_{30} I_{1} 15-20 \mathrm{~min}$ after perfusing neurons through the recording electrode with anti-A. Sympathetic SCG neurons ( $1 \mu \mathrm{m}$ anti-A), $n=6$; parasympathetic Subm neurons perfused intracellularly with control solution (Ctrl), $n=6 ; 1$ $\mu \mathrm{m}$ anti-A, $n=8 ; 2 \mu \mathrm{m}$ anti-A, $n=6 ; 10 \mu \mathrm{m}$ anti-A, $n=6$. The values are the mean \pm SEM. For Subm neurons ( 0 and 1 $\mu \mathrm{M})$ versus SCG neurons $(1 \mu \mathrm{M}), p<0.05$; for Subm neurons $(10 \mu \mathrm{m}$ anti-A) versus $S C G$ neurons $(1 \mu \mathrm{m}$ anti-A), $p>0.1$. 
A

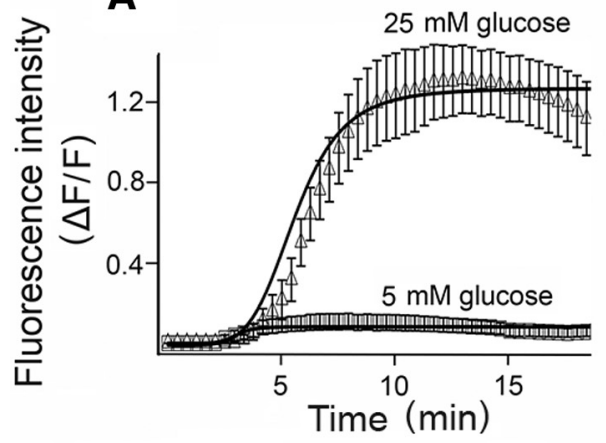

B

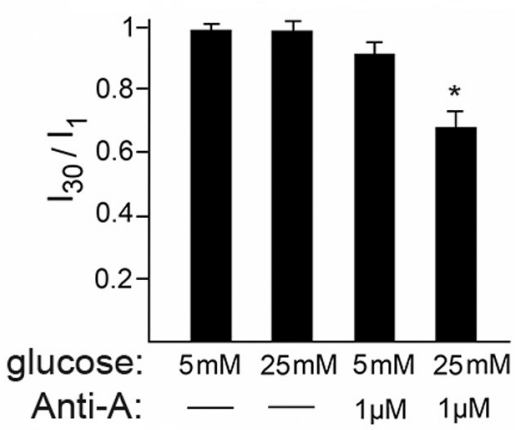

Figure 7. Hyperglycemia together with partial blockade of mitochondria complex III elevates cytosolic ROS on parasympathetic neurons and inactivates nAChRs. $\boldsymbol{A}$, Average increase in ROS-induced DCFDA fluorescence in parasympathetic Subm neurons cultured in $5 \mathrm{~mm}$ glucose for $14 \mathrm{~d}$ or in $5 \mathrm{~mm}$ glucose for $7 \mathrm{~d}$ and $25 \mathrm{~mm}$ glucose for $7 \mathrm{~d}(n=6)$ and then perfused through the recording electrode with $1 \mu \mathrm{m}$ anti-A. The data represent the mean $\Delta F / F$ and fit with a Hill function (solid lines), $p<0.001 . B$, $I_{30} / I_{1}$ after perfusing neurons through the recording electrode with $1 \mu \mathrm{m}$ anti-A for $15-20 \mathrm{~min}$ ( $n=12$ for $5 \mathrm{~mm}$ glucose; $n=14$ for $25 \mathrm{~mm}$ glucose; $n=9$ for $5 \mathrm{~mm}$ glucose and $1 \mu \mathrm{m}$ anti-A; $n=18$ for 25 mм glucose and $1 \mu \mathrm{m}$ anti-A). $I_{30} / I_{1}$ was significantly less for neurons grown with $25 \mathrm{~mm}$ glucose and perfused intracellularly with $1 \mu \mathrm{m}$ anti-A compared with those in $5 \mathrm{~mm}$ glucose with or without anti-A or those grown in $25 \mathrm{~mm}$ glucose without anti-A $\left(^{*} p<0.05\right)$.

unit composition of $\mathrm{nAChRs}$ on autonomic neurons in rodents is unknown, it is highly probable that the receptors contain $\alpha 3, \beta 4$, and/or $\beta 2$ subunits; all three subunits contain the highly conserved Cys residues located near the intracellular mouth of receptors and, therefore, likely targets of ROS, as we showed for the Cys on $\alpha 3$ (Campanucci et al., 2010; Krishnaswamy and Cooper, 2012). On the other hand, some nAChRs on chick ciliary ganglion neurons also contain an $\alpha 5$ subunit (Conroy and Berg 1995). It is not known whether the incorporation of $\alpha 5$ in the receptor pentameter alters the receptor's sensitivity to ROS.

Steady-state ROS levels are a balance between ROS production and ROS neutralization by antioxidants and ROS scavengers. To investigate this differential effect of hyperglycemia on autonomic ganglia, we combined ROS imaging with electrophysiology. Focusing on postganglionic neurons, our results show that hyperglycemia produces considerably smaller elevations in cytosolic ROS in parasympathetic neurons compared with sympathetic neurons, a result suggesting that sympathetic neurons have lower ROS buffering capacity than parasympathetic neurons. We observed similar results when blocking complex III of the mitochondrial ETC with anti-A. At $1 \mu \mathrm{M}$, anti-A produced greater elevations in cytosolic ROS in sympathetic neurons than in parasympathetic neurons. A likely explanation for this differential response to mild oxidative stress is that these neurons use different neurotransmitters. Specifically, sympathetic neurons synthesize catecholamines and are at high risk for oxidative stress because molecules involved in the synthesis of the catecholamines, such as tyrosine hydroxylase and monoamine oxidase, produce $\mathrm{H}_{2} \mathrm{O}_{2}$ as normal byproducts of their activities (Coyle and Puttfarcken, 1993). In addition, catecholamines undergo auto-oxidation and produce $\mathrm{H}_{2} \mathrm{O}_{2}$. Accumulated $\mathrm{H}_{2} \mathrm{O}_{2}$ slowly decomposes to the highly reactive hydroxyl radical, a process that is accelerated markedly in the presence of $\mathrm{Fe}^{2+}$ by the Fenton reaction. When subjected to additional oxidative stress, possibly from enhanced glucose metabolism in people with diabetes, sympathetic neurons have difficulty keeping ROS in balance. On the other hand, the neurotransmitter used by parasympathetic neurons is acetylcholine, whose byproducts are not pro-oxidant. As such, parasympathetic neurons presumably have higher levels of antioxidants, such as glutathione, compared with sympathetic neurons, and therefore they are better able to buffer ROS. If so, it might explain why parasympathetic neurons require high concentrations of anti-A to elevate cytosolic ROS.

With parasympathetic neurons, neither hyperglycemia nor $1 \mu \mathrm{M}$ anti-A alone produced a significant elevation in cytosolic ROS, and the ACh-evoked currents on these neurons are stable; however, when $1 \mu \mathrm{M}$ anti-A is applied to parasympathetic neurons grown in hyperglycemic conditions, there is a strong synergistic elevation in ROS, and these elevated ROS cause an irreversible, use-dependent rundown of the ACh-evoked currents, in keeping with our model for how ROS inactivate nAChRs (Krishnaswamy and Cooper, 2012). Similarly, synaptic transmission in parasympathetic ganglia in diabetic animals is not depressed, nor is it significantly depressed when recording with anti-A in the electrode. Conversely, recording synaptic transmission from parasympathetic ganglia of diabetic mice with anti-A in the recording electrode significantly depressed nerve-evoked EPSPs. These results imply that, although diabetes alone does not affect synaptic transmission in parasympathetic ganglia, it will depress synaptic transmission if a subject succumbs to a disease that either elevates ROS or compromises the antioxidant pathways or ROS scavenger molecules neurons.

Although our experiments demonstrate that diabetes does not disrupt synaptic transmission in parasympathetic ganglia, they do not rule out the possibility that parasympathetic function is not perturbed. For example, diabetes may alter transmitter release from parasympathetic nerve terminals, as it does for motor nerve terminals at the neuromuscular junction (Kimura et al., 1993; Ramji et al., 2007; Souayah et al., 2009), and/or diabetes may alter synaptic drive on parasympathetic preganglionic neurons in the dorsal motor nucleus of the vagus (Sohn et al., 2013). Although we have not investigated the overall performance of the parasympathetic nervous systems in these diabetic mice, we saw little evidence of abnormal parasympathetic function, as is seen in $\alpha 3 \mathrm{KO}$ mice that have no synaptic transmission in any of the autonomic ganglia or the adrenal medullae.

In addition to sympathetic and parasympathetic ganglia, we investigated synaptic transmission between the preganglionic nerve and adrenal chromaffin cells, a topic that has received little attention. Adrenal chromaffin cells have been shown to express a number of different nAChR subtypes (López et al., 1998; Di Angelantonio et al., 2003; Sala et al., 2008), and there has been some uncertainty about which subtypes are present at synapses with preganglionic nerve terminals. Our experiments with $\alpha 3 \mathrm{KO}$ mice resolve this issue by establishing that the nerve-evoked EPSPs on adrenal chromaffin cells are mediated by $\alpha 3$ containing nAChRs. Relevantly, we show that these synapses are depressed significantly in diabetic animals.

The depression of synaptic transmission in the adrenal medulla and in the prevertebral sympathetic ganglia may have implications for insulin-induced hypoglycemia, a serious, acute complication of type 1 diabetes (Cryer et al., 1986; Havel and Ahren, 1997; Taborsky et al., 1998; Cryer, 2012). Briefly, to protect against a fall in blood glucose, pancreatic $\alpha$ cells are stimulated to release glucagon. The major stimulants to $\alpha$ cells are 
norepinephrine released from sympathetic nerves originating from neurons in prevertebral ganglia and circulating epinephrine released from chromaffin cells in the adrenal medullae. In diabetics, it is likely that the functional sympathetic innervation to $\alpha$ cells is reduced because synaptic transmission in prevertebral ganglia is depressed. In addition, a defect in nerve-evoked synaptic transmission at synapses on chromaffin cells results in a decrease in circulating epinephrine. Reduced activity in the sympathoadrenal system in diabetics would have severe consequences for glucagon release by pancreatic $\alpha$ cells, and by implication, impair the major counter-regulatory mechanisms that defend against insulin-induced hypoglycemia (Havel and Ahren, 1997; Taborsky et al., 1998; Cryer, 2005).

\section{References}

Campanucci VA, Krishnaswamy A, Cooper E (2008) Mitochondrial reactive oxygen species inactivate neuronal nicotinic acetylcholine receptors and induce long-term depression of fast nicotinic synaptic transmission. J Neurosci 28:1733-1744. CrossRef Medline

Campanucci VA, Krishnaswamy A, Cooper E (2010) Diabetes depresses synaptic transmission in sympathetic ganglia by inactivating nAChRs through a conserved intracellular cysteine residue. Neuron 66:827-834. CrossRef Medline

Colomer C, Olivos-Oré LA, Vincent A, McIntosh JM, Artalejo AR, Guérineau NC (2010) Functional characterization of alpha9-containing cholinergic nicotinic receptors in the rat adrenal medulla: implication in stressinduced functional plasticity. J Neurosci 30:6732-6742. CrossRef Medline

Conroy WG, Berg DK (1995) Neurons can maintain multiple classes of nicotinic acetylcholine receptorsdistinguished by different subunit compositions. J Biol Chem 270:4424-4431. CrossRef Medline

Coyle JT, Puttfarcken P (1993) Oxidative stress, glutamate, and neurodegenerative disorders. Science 262:689-695. CrossRef Medline

Criado M, Domínguez del Toro E, Carrasco-Serrano C, Smillie FI, Juíz JM, Viniegra S, Ballesta JJ (1997) Differential expression of alpha-bungarotoxinsensitive neuronal nicotinic receptors in adrenergic chromaffin cells: a role for transcription factor Egr-1. J Neurosci 17:6554-6564. Medline

Cryer PE (2005) Mechanisms of hypoglycemia-associated autonomic failure and its component syndromes in diabetes. Diabetes 54:3592-3601. CrossRef Medline

Cryer PE (2012) Severe hypoglycemia predicts mortality in diabetes. Diabetes Care 35:1814-1816. CrossRef Medline

Cryer PE, White NH, Santiago JV (1986) The relevance of glucose counterregulatory systems to patients with insulin-dependent diabetes mellitus. Endocr Rev 7:131-139. CrossRef Medline

Di Angelantonio S, Matteoni C, Fabbretti E, Nistri A (2003) Molecular biology and electrophysiology of neuronal nicotinic receptors of rat chromaffin cells. Eur J Neurosci 17:2313-2322. CrossRef Medline

Freeman R (2005) Autonomic peripheral neuropathy. Lancet 365:12591270. CrossRef Medline

Havel PJ, Ahren B (1997) Activation of autonomic nerves and the adrenal medulla contributes to increased glucagon secretion during moderate insulin-induced hypoglycemia in women. Diabetes 46:801-807. CrossRef Medline

Kimura I, Okazaki M, Kimura M (1993) Streptozocin-diabetes modifies acetylcholine release from mouse phrenic nerve terminal and presynaptic sensitivity to succinylcholine. Jpn J Pharmacol 62:35-41. CrossRef Medline

Krishnaswamy A, Cooper E (2009) An activity-dependent retrograde signal induces the expression of the high-affinity choline transporter in cholinergic neurons. Neuron 61:272-286. CrossRef Medline

Krishnaswamy A, Cooper E (2012) Reactive oxygen species inactivate neu- ronal nicotinic acetylcholine receptors through a highly conserved cysteine near the intracellular mouth of the channel: implications for diseases that involve oxidative stress. J Physiol 590:39-47. CrossRef Medline

Kuehl M, Stevens MJ (2012) Cardiovascular autonomic neuropathies as complications of diabetes mellitus. Nat Rev Endocrinol 8:405-416. CrossRef Medline

López MG, Montiel C, Herrero CJ, García-Palomero E, Mayorgas I, Hernández-Guijo JM, Villarroya M, Olivares R, Gandía L, McIntosh JM, Olivera BM, García AG (1998) Unmasking the functions of the chromaffin cell alpha7 nicotinic receptor by using short pulses of acetylcholine and selective blockers. Proc Natl Acad Sci U S A 95:14184-14189. CrossRef Medline

Miller SM, Hanani M, Kuntz SM, Schmalz PF, Szurszewski JH (1996) Light, electron, and confocal microscopic study of the mouse superior mesenteric ganglion. J Comp Neurol 365:427-444. CrossRef Medline

Ramji N, Toth C, Kennedy J, Zochodne DW (2007) Does diabetes mellitus target motor neurons? Neurobiol Dis 26:301-311. CrossRef Medline

Rassadi S, Krishnaswamy A, Pié B, McConnell R, Jacob MH, Cooper E (2005) A null mutation for the alpha3 nicotinic acetylcholine (ACh) receptor gene abolishes fast synaptic activity in sympathetic ganglia and reveals that ACh output from developing preganglionic terminals is regulated in an activity-dependent retrograde manner. J Neurosci 25:85558566. CrossRef Medline

Sala F, Nistri A, Criado M (2008) Nicotinic acetylcholine receptors of adrenal chromaffin cells. Acta Physiol (Oxf) 192:203-212. CrossRef Medline

Schmidt RE (1996) Neuropathology of human sympathetic autonomic ganglia. Microsc Res Tech 35:107-121. Medline

Schmidt RE, Parvin CA, Green KG (2008) Synaptic ultrastructural pathology anticipates the development of neuroaxonal dystrophy in the sympathetic ganglia of aged and diabetic mice. J Neuropathol Exp Neurol 67: 1066-1086. CrossRef Medline

Schmidt RE, Green KG, Snipes LL, Feng D (2009) Neuritic dystrophy and neuronopathy in Akita (Ins2Akita) diabetic mouse sympathetic ganglia. Exp Neurol 216:207-218. CrossRef Medline

Sohn JW, Harris LE, Berglund ED, Liu T, Vong L, Lowell BB, Balthasar N, Williams KW, Elmquist JK (2013) Melanocortin 4 receptors reciprocally regulate sympathetic and parasympathetic preganglionic neurons. Cell 152:612-619. CrossRef Medline

Souayah N, Potian JG, Garcia CC, Krivitskaya N, Boone C, Routh VH, McArdle JJ (2009) Motor unit number estimate as a predictor of motor dysfunction in an animal model of type 1 diabetes. Am J Physiol Endocrinol Metab 297:E602-E608. CrossRef Medline

Taborsky GJ Jr, Ahrén B, Havel PJ (1998) Autonomic mediation of glucagon secretion during hypoglycemia: implications for impaired alpha-cell responses in type 1 diabetes. Diabetes 47:995-1005. CrossRef Medline

Tompkins JD, Vizzard MA, Parsons RL (2013) Synaptic transmission at parasympathetic neurons of the major pelvic ganglion from normal and diabetic male mice. J Neurophysiol 109:988-995. CrossRef Medline

Ullian EM, McIntosh JM, Sargent PB (1997) Rapid synaptic transmission in the avian ciliary ganglion is mediated by two distinct classes of nicotinic receptors. J Neurosci 17:7210-7219. Medline

Vinik AI, Ziegler D (2007) Diabetic cardiovascular autonomic neuropathy. Circulation 115:387-397. CrossRef Medline

Vinik AI, Maser RE, Mitchell BD, Freeman R (2003) Diabetic autonomic neuropathy. Diabetes Care 26:1553-1579. CrossRef Medline

Xu X, Gelber S, Orr-Urtreger A, Armstrong D, Lewis RA, Ou CN, Patrick J, Role L, De Biasi M, Beaudet AL (1999) Megacystis, mydriasis, and ion channel defect in mice lacking the $\alpha 3$ neuronal nicotinic acetylcholine receptor. Proc Natl Acad Sci U S A 96:5746-5751. CrossRef Medline

Zhang ZW, Coggan JS, Berg DK (1996) Synaptic currents generated by neuronal acetylcholine receptors sensitive to alpha-bungarotoxin. Neuron 17:1231-1240. CrossRef Medline 